Artikel Penelitian

\title{
Natrium Metabisulfit sebagai Anti-Browning Agent pada Pencoklatan Enzimatik Rebung Ori (Bambusa Arundinacea)
} Sodium Metabisulfite as Anti-Browning Agent in Enzymatic Browning of Bamboo Shoot (Bambusa Arundinacea)

Dyah Hesti Wardhani", Ardha Eri Yuliana, dan Atiqoh Sabrina Dewi

Jurusan Teknik Kimia, Fakultas Teknik, Universitas Diponegoro, Semarang

Korespondensi dengan penulis (dhwardhani@undip.ac.id)

Artikel ini dikirim pada tanggal 19 Juni 2016 dan dinyatakan diterima tanggal 13 Oktober 2016. Artikel ini juga dipublikasi secara online melalui www.jatp.ift.or.id. Hak cipta dilindungi undang-undang. Dilarang diperbanyak untuk tujuan komersial.

Diproduksi oleh Indonesian Food Technologists $®$ (อ2016

\begin{abstract}
Abstrak
Rebung mengandung senyawa fenolik mencapai 0,204 EAG/gr rebung dan aktivitas enzim polifenol oksidase (PPO) mencapai 0,333 Unit, sehingga rawan terhadap reaksi pencoklatan enzimatis pada suhu kamar. Pencoklatan enzimatis disebabkan oleh teraktifkannya enzim PPO dengan bantuan oksigen. Sodium metabisulfit (SMB) sebagai anti-browning agent membentuk ikatan disulfida dengan enzim PPO sehingga menghambat pengikatan dengan oksigen. Tujuan penelitian ini adalah mempelajari pengaruh konsentrasi natrium metabisulfit, waktu perendaman, dan $\mathrm{pH}$ terhadap derajat putih, total fenol, dan aktivitas enzim PPO pada rebung selama penyimpanan. Penelitian ini menggunakan rebung ori (Bambusa arundinacea) yang diiris bentuk chip bulat dengan ketebalan 0,5 cm kemudian direndam larutan SMB (0, 1000, 2000 dan 3000 ppm) selama 15, 30, 45, 60 menit dengan variabel $\mathrm{pH}$ perendaman $(3,4,6$ dan 8$)$. Respon yang diamati berupa derajat putih, total fenol dan aktivitas enzim PPO pada rebung yang disimpan beberapa hari. Hasil penelitian menunjukan aktivitas enzim PPO semakin kecil sedangkan total fenol dan derajat putih semakin besar, seiring dengan bertambahnya konsentrasi SMB dan waktu perendaman. Konsentrasi SMB terbaik untuk mencegah pencoklatan adalah $3000 \mathrm{ppm}$ dengan perendaman selama 45 menit. Perendaman pada pH 3 mampu menekan aktifitas enzim PPO sehingga bisa didapatkan derajat putih tertinggi meskipun telah disimpan selama 3 hari.
\end{abstract}

Kata kunci: derajat putih, pencoklatan, enzim PPO, rebung, natrium metabisulfit, total fenolik.

\begin{abstract}
Bamboo shoot contained up to 0.204 EAG / gr fresh bamboo shoots and 0.333 units of the enzyme polyphenol oxidase (PPO) activity. Therefore, it susceptible for enzymatic browning reaction at room temperature. The browning activities were due to activated of the PPO enzymes with the aid of oxygen. Sodium metabisulphite (SMB) as an anti-browning agent was formed a disulfide bond with the PPO enzyme thus inhibited the binding of the oxygen. The purpose of this research was to study the effect of concentration of SMB, soaking time, and the $\mathrm{pH}$ on degree of whiteness, total phenolics and PPO activity of the bamboo shoots during storage. This study used ori bamboo shoots (Bambusa arundinacea) which was sliced round chip shape with a thickness of $0.5 \mathrm{~cm}$ and then soaked in a solution of SMB (0,1000, 2000 and 3000 ppm) for 15, 30, 45, 60 min with varied in pH immersion (3, 4, 6 and 8). Responses were observed in degree of whiteness, total phenolics and PPO activity of bamboo shoots. Increasing SMB concentration and soaking time affected PPO activity negatively but retained the total phenolics and degree of whiteness. Soaking the bamboo shoot using 3000 ppm of SMB for $45 \mathrm{~min}$ at pH 3 were able to suppress the PPO activity and maintained the highest degree of whiteness even after stored for 3 days.
\end{abstract}

Keywords: degree of whiteness, browning, PPO enzyme, bamboo shoot, sodium metabisulphite, total phenolics.

\section{Pendahuluan}

Rebung merupakan tunas muda tanaman bambu dengan salah satu ujungnya meruncing yang muncul di permukaan dasar rumpun, memiliki panjang 20-30 $\mathrm{cm}$. Umur pemanenan tergantung spesies, berat, ukuran yang dipengaruhi lingkungan sekitar. Hampir semua rebung dapat dimakan. Rebung dikenal rendah lemak dan kolesterol, rendah kalori dan kaya nutrisi. Nutrisi utama rebung adalah protein dan karbohidrat, asam amino, mineral, fiber dan garam inorganik. Mineral utama pada rebung meliputi kalium, kalsium, mangan, zink, besi dan kromium. Selain itu rebung mengandung antioksidant seperti flavones, phenol dan steroid. Dengan tingginya nutrisi yang dikandung, rebung menjadi material yang berharga untuk diolah menjadi makanan sehat, material farmasi maupun aditif (Chongtham et al., 2011, Choudhury et al., 2012). Salah satu faktor yang menyebabkan penurunan kualitas rebung adalah munculnya pencoklatan di permukaannya.

Reaksi pencoklatan secara enzimatik merupakan reaksi yang terjadi antara enzim polyfenoloksidase (PPO) dan peroksidase (POD) dengan polifenol yang membentuk quinon yang kemudian terpolimerisasi menghasilkan warna coklat. Pencoklatan secara enzimatik tidak hanya berpengaruh secara penampakan, tetapi juga rasa dan nutrisi makanan (Cortez-Vega et al., 2008) 
Pada kondisi normal, polifenol yang merupakan substrat bagi reaksi pencoklatan dan enzim baik PPO maupun POD menempati bagian sel yang berbeda. Polifenol ditemukan di bagian vakuola sel sedangkan PPO dan POD berlokasi di sitoplasma. Reaksi pencoklatan akan terjadi manakala substrat dan enzim bercampur dan melibatkan oksigen dalam reaksinya. Pengirisan, pengupasan, tumbukan dan pembusukan merupakan beberapa proses yang memicu dimulainya reaksi pencoklatan. Untuk menghindari fenomena ini, beberapa metode dilakukan diantaranya dengan menonaktifkan enzim atau dengan menambahkan agen anti pencoklatan yang dapat memghindari terjadinya kontak antara enzim dengan substrat (loannou and Ghoul, 2013).

Cara penonaktifan PPO bisa dilakukan didasarkan pada mekanisme reaksi pencoklatan misalnya, melalui penghilangan oksigen yang merupakan reaktan dalam reaksi pencoklatan, denaturasi protein enzim, melindungi interaksi dengan gugus prostetik tembaga dan interaksi dengan senyawa fenolik ataupun quinon (Mesquita and Queiroz, 2010). Salah satu senyawa yang digunakan dalam menonaktifkan PPO adalah sulfit. Sulfit merupakan inhibitor kuat yang efektif dalam menghambat pencoklatan dan sudah lama digunakan dalam industri makanan. Akan tetapi penggunaan yang berlebihan dilarang oleh WHO karena akan berdampak negatif khususnya bagi penderita asma (Tan et al., 2015).

Dalam pengolahan setelah panen, rebung mengalami perlakuan seperti pengupasan dan pemotongan yang dapat memicu terjadinya perubahan degenaratif dalam bentuk pencoklatan. Untuk itu perlu dilakukan usaha untuk menunda dan mengurangi reaksi pencoklatan secara enzimatik yang diharapkan akan memperpanjang dan menjaga kualitas rebung kupasan.

Sodium metabisulfit (SMB) sebagai anti-browning sudah digunakan pada berbagai buah maupun sayuran (loannou and Ghoul, 2013), tetapi penelitian penggunaan natrium metabisulfit untuk mencegah pencoklatan pada rebung masih belum banyak dipelajari. Karenanya tujuan dari penelitian ini adalah untuk mempelajari pengaruh perlakuan SMB terhadap rebung khususnya waktu perendaman, konsentrasi $\mathrm{SMB}$, dan $\mathrm{pH}$ terhadap derajat putih, total fenol dan aktivitas enzim PPO pada rebung. Penelitian ini diharapkan memberikan data kondisi perlakuan menggunakan SMB yang efektif untuk menahan pencoklatan pada rebung.

\section{Materi dan Metode \\ Materi}

Rebung ori yang diiris bentuk chip setebal 0,5 $\mathrm{cm}$, sodium metabisulfit (SMB) sebagai anti-browning agent (1000 ppm, 2000 ppm, 3000 ppm), aquades, etanol, natrium karbonat, reagen Folin-Ciocalteu, asam galat dan buffer $\mathrm{Na}$ asetat-asam asetat $0,01 \mathrm{M} \mathrm{pH} 5$. Peralatan yang dipakai dalam penelitian ini vortex, blender Miyako BL-151 PR/PA, Sentrifuge Hettich EBa
200, UV-VIS Spectrophotometer SP 300 Optima, dan kromameter Minolta CR 300,

\section{Metode Penelitian}

Penelitian ini dibagi menjadi dua tahapan yaitu kajian i) konsentrasi SMB dan waktu perendaman, dan ii) $\mathrm{pH}$ perendaman. Pada tahapan pertama, rebung dalam bentuk chips direndam dengan SMB (1000 ppm, $2000 \mathrm{ppm}$ dan $3000 \mathrm{ppm})$ dengan rasio $1: 5(\mathrm{~g} / \mathrm{ml})$. Setelah waktu perendaman tertentu $(15,30,45$ dan 60 menit) rebung ditiriskan dan dicuci untuk kemudian diuji derajat putih, total fenolik dan aktifitas enzim PPO (Nastiti et al., 2014). Simpan rebung pada suhu ruang dan setiap waktu tertentu sampel diambil untuk dianalisa. Untuk kajian pengaruh $\mathrm{pH}$, rebung direndam dengan kondisi terbaik yang diperoleh dari tahapan sebelumnya (3000 rpm, 45 menit) pada pH 3, 4, 6 dan 8. Selanjutnya sampel mengalami perlakuan yang sama dengan sampel pada tahapan sebelumnya.

\section{Analisa}

Derajat Putih. Rebung yang sudah dihaluskan, dianalisis warnanya berdasarkan sistem warna Hunter menggunakan Konica Minolta Chromameter CR-300. Derajat putih dinyatakan dengan $L^{*}$.

Total fenolik. Uji konsentrasi total fenolik dilakukan mengikuti metode dari Luo et al., (2012) yang menggunakan asam galat sebagai standar. Lima gram rebung disuspensikan dengan $20 \mathrm{ml}$ etanol $80 \%$. Setelah 60 detik, suspensi disentrifugasi $4000 \mathrm{rpm}$ selama 15 menit. Satu $\mathrm{ml}$ supernatant yang didapatkan, direaksikan dengan $1 \mathrm{ml}$ reagen Folin-Ciocalteu, $10 \mathrm{ml}$ $\mathrm{Na}_{2}(\mathrm{CO})_{3}(7 \%)$ kemudian ditambah aquades hingga volume $25 \mathrm{ml}$ dan kemudian divortek. Setelah dibiarkan selama 1 jam, absorbansi sampel dibaca pada panjang gelombang $750 \mathrm{~nm}$. Konsentrasi total fenolik dinyatakan sebagai mg ekuivalen asam galat (mg EAG) per berat rebung segar.

Aktifitas enzim PPO. Metode uji aktifitas enzim PPO mengikuti metode Gardjito et al., 2006. Enzim diekstraski dari $15 \mathrm{~g}$ rebung menggunakan $60 \mathrm{ml}$ aquades selama 1 menit kemudian disaring dengan cepat. Filtrat ditempatkan dalam tabung reaksi yang direndam dalam es yang mulai mencair. Ekstrak enzim $(1 \mathrm{ml})$ ditempatkan pada tabung reaksi bersama dengan 2,6 ml buffer $\mathrm{Na}$ asetat-asam asetat $0,01 \mathrm{M} \mathrm{pH}$ 5 dan $3 \mathrm{ml}$ asam galat $0,5 \mathrm{M}$. Setelah 15 menit, larutan diukur absorbansinya pada panjang gelombang 420 $\mathrm{nm}$. Aktifitas enzim PPO (1 unit) dinyatakan sebagai kemampuan enzim untuk mereaksikan $1 \mathrm{ppm}$ asam galat per satuan waktu.

\section{Hasil dan Pembahasan}

Setelah sampel ditreatmen pada kondisi variasi tertentu menggunakan konsentrasi SMB $(1000,2000$ dan $3000 \mathrm{ppm})$, waktu perendaman (0, 5, 30, 45 dan 60 menit) dan $\mathrm{pH}(3,4,6$ dan 8) sampel disimpan pada suhu ruang hingga waktu tertentu untuk diuji warna, total fenolik dan aktifitas enzim PPOnya. Warna suatu bahan makanan dinyatakan dalam $L^{*} a^{*} \quad b^{*}$ yang merupakan standar untuk pengukuran warna. $L^{*}$ 
menyatakan lightness atau derajat putih yang dinyatakan dalam rentang 0 (hitam) -100 (putih). Semakin tinggi nilai $L^{*}$ menunjukan sampel semakin putih (Nems et al., 2015).

\section{Pengaruh Konsentrasi dan Lama Perendaman}

Tabel 1, 2 dan 3 menunjukan pengaruh konsentrasi SMB dan waktu perendaman terhadap derajat putih, total senyawa fenolik dan aktivitas PPO rebung setelah disimpan selama 3 hari. Tabel 1 menunjukan sampel tanpa perlakuan mengalami penurunan derajat putih dengan cepat pada hari ke 2 . Hal ini disebabkan karena sampel tanpa perlakuan mengalami pencoklatan. Pengupasan dan pemotongan rebung menyebabkan rusaknya jaringan sel dimana PPO berada yang menyebabkan enzim dapat bereaksi dengan senyawa fenolik yang juga dilepaskan oleh vakuola yang terkoyak (lannou and Ghoul, 2013). Pengupasan menyebabkan PPO mengkatalis dua reaksi dengan adanya oksigen yaitu hidroksilasi monofenol dan oksidasi o-diphenol menjadi o-quinon yang diikuti dengan polimerisasi non-enzimatik quinon menghasilkan melanin pigmen dengan warna gelap (Queiroz, 2008). Tabel 2 dan 3 menunjukan pada hari ke-0 penyimpanan, rebung tanpa perlakuan mempunyai aktifitas enzim PPO 0,333 $\mathrm{U}$ dan total fenolik 0,2043 mg EAG/g rebung. Semakin lama waktu penyimpanan derajat putih rebung yang tanpa diberi perlakuan menurun dengan cepat. Hal ini sesuai dengan hasil yang ditunjukan pada Tabel 2. dimana aktifitas enzim PPO rebung yang tanpa perlakuan meningkat dengan cepat selama waktu penyimpanan.

Tabel 1 menunjukan kecepatan pencoklatan rebung berbeda-beda dipengaruhi oleh konsentrasi SMB dan waktu perendaman. Secara umum konsentrasi dan waktu perendaman dengan SMB berpengaruh positif dalam menurunkan laju pencoklatan rebung. Perendaman selama 45-60 menit menggunakan konsentrasi 3000 ppm paling efektif dalam menurunkan kecepatan pencoklatan rebung. Penambahan waktu hingga 60 menit tidak berpengaruh terhadap derajat putih rebung. Hal ini kemungkinan disebabkan pada perendaman selama 45 menit, rebung sudah mendekati kondisi jenuhnya sehingga perendaman untuk waktu yang lebih lama relatif tidak meningkatkan derajat putihmya. Hasil serupa juga dilaporkan oleh Prabasini et al. (2013) pada tepung labu kuning. Penetrasi SMB akan efektif pada material

Tabel 1. Pengaruh waktu dan konsentrasi SBM terhadap derajat putih sampel rebung yang disimpan selama waktu tertentu pada suhu kamar

\begin{tabular}{cccccc}
\hline \multirow{2}{*}{$\begin{array}{c}\text { Waktu } \\
\text { perendaman } \\
\text { (menit) }\end{array}$} & $\begin{array}{c}\text { Konsentrasi } \\
\text { Natrium } \\
\text { Metabisulfit } \\
(\text { ppm) }\end{array}$ & \multicolumn{4}{c}{ Derajat Putih } \\
\cline { 3 - 5 } (kontrol) & 0 & 71,59 & \multicolumn{3}{c}{ Waktu penyimpanan (hari) } \\
& 1000 & 71,59 & 70,63 & 59,25 & 59,25 \\
15 & 2000 & 71,59 & 70,63 & 59,25 & 59,25 \\
& 3000 & 71,59 & 70,63 & 59,25 & 59,25 \\
& 1000 & 71,59 & 70,63 & 59,25 & 59,25 \\
30 & 2000 & 71,59 & 70,63 & 69,69 & 59,25 \\
& 3000 & 71,59 & 70,63 & 69,69 & 59,25 \\
& 1000 & 71,59 & 70,63 & 69,69 & 69,69 \\
& 2000 & 71,59 & 71,59 & 69,69 & 59,25 \\
& 3000 & 71,59 & 71,59 & 69,69 & 69,69 \\
60 & 1000 & 71,59 & 71,59 & 70,63 & 70,63 \\
& 2000 & 71,59 & 71,59 & 69,69 & 69,69 \\
\end{tabular}

Tabel 2. Pengaruh konsentrasi natrium metabisulfit dan waktu perendaman terhadap aktifitas enzim PPO pada rebung yang disimpan selama waktu tertentu pada suhu kamar

\begin{tabular}{cccccc}
\hline \multirow{2}{*}{$\begin{array}{c}\text { Waktu } \\
\text { perendaman } \\
\text { (menit) }\end{array}$} & $\begin{array}{c}\text { Konsentrasi Natrium } \\
\text { Metabisulfit (ppm) }\end{array}$ & 0 & \multicolumn{3}{c}{ Aktifitas Enzim PPO (Unit) } \\
\cline { 3 - 6 } (kontrol) & 0 & 0,333 & 0,739 & 2 \\
& 1000 & 0,333 & 0,527 & 0,856 & 0,856 \\
15 & 2000 & 0,333 & 0,527 & 0,856 & 0,856 \\
& 3000 & 0,333 & 0,527 & 0,739 & 0,856 \\
30 & 1000 & 0,333 & 0,527 & 0,739 & 0,856 \\
& 2000 & 0,333 & 0,527 & 0,739 & 0,856 \\
45 & 3000 & 0,333 & 0,527 & 0,527 & 0,739 \\
& 1000 & 0,333 & 0,527 & 0,527 & 0,739 \\
60 & 2000 & 0,333 & 0,333 & 0,739 & 0,739 \\
& 3000 & 0,333 & 0,333 & 0,527 & 0,739 \\
& 1000 & 0,333 & 0,527 & 0,739 & 0,527 \\
\end{tabular}


Tabel 3. Pengaruh konsentrasi natrium metabisulfit dan waktu perendaman terhadap total fenol pada rebung

\begin{tabular}{|c|c|c|c|c|c|}
\hline \multirow{3}{*}{$\begin{array}{l}\text { Waktu perendaman } \\
\text { (menit) }\end{array}$} & \multirow{3}{*}{$\begin{array}{c}\text { Konsentrasi Natrium } \\
\text { Metabisulfit (ppm) }\end{array}$} & \multicolumn{4}{|c|}{ Total Fenolik (EAG/gr rebung) } \\
\hline & & \multicolumn{4}{|c|}{ Waktu penyimpanan (hari) } \\
\hline & & 0 & 1 & 2 & 3 \\
\hline- & 0 & 0,2043 & 0,2043 & 0,1568 & 0,1568 \\
\hline \multirow[t]{3}{*}{15} & 1000 & 0,2043 & 0,2043 & 0,1568 & 0,1568 \\
\hline & 2000 & 0,2043 & 0,2043 & 0,1568 & 0,1568 \\
\hline & 3000 & 0,2043 & 0,2043 & 0,1568 & 0,1568 \\
\hline \multirow[t]{3}{*}{30} & 1000 & 0,2043 & 0,2043 & 0,1568 & 0,1568 \\
\hline & 2000 & 0,2043 & 0,2043 & 0,1568 & 0,1568 \\
\hline & 3000 & 0,2043 & 0,2043 & 0.1684 & 0,1568 \\
\hline \multirow[t]{3}{*}{45} & 1000 & 0,2043 & 0,2043 & 0,1684 & 0,1568 \\
\hline & 2000 & 0,2101 & 0,2043 & 0,1684 & 0,1568 \\
\hline & 3000 & 0,2101 & 0,2043 & 0,1684 & 0,1568 \\
\hline \multirow[t]{3}{*}{60} & 1000 & 0,2101 & 0,2101 & 0,1684 & 0,1568 \\
\hline & 2000 & 0,2101 & 0,2101 & 0,1684 & 0,1684 \\
\hline & 3000 & 0,2101 & 0,2101 & 0,1684 & 0,1684 \\
\hline
\end{tabular}

yang lunak. Konsentrasi SBM yang semakin tinggi serta waktu perendaman yang semakin lama akan meninggalkan residu sulfit yang semakin banyak pada kelapa muda (Mohpraman and Siriphanich, 2012).

Pada saat terlarut SMB akan membentuk campuran dissosiasi $\mathrm{SO}_{3}{ }^{2-}$ dan $\mathrm{HSO}_{3}{ }^{-5}$. Ada 3 mekanisme inhibisi pencoklatan oleh sulfite, yaitu: inhibisi reaksi searah PPO, reduksi o-quinon sehingga membalikan arah reaksi enzimatik, dan pembentukan produk tambahan antara sulfite dan o-quinon, sehingga mencegah terjadinya reaksi pencoklatan lebih lanjut lagi (Kuijpers et al., 2012). Produk disosiasi tersebut juga bisa bereaksi dengan aldehid, keton, dekstrin, dan senyawa lain di buah yang dilindunginya (Coskun et al., 2013).

Tabel 2 menunjukkan perendaman dengan SMB menurunkan aktifitas PPO dibanding rebung tanpa perlakuan. Hasil serupa dilaporkan oleh Amiour and Hambaba (2016) pada perendaman buah kurma dengan SMB. Tabel 2. juga memperlihatkan waktu penyimpanan yang semakin lama menyebabkan aktifitas enzim PPO semakin tinggi. Hal ini sejalan dengan kajian Cortez-Vega et al. (2008) dan Holzwarth et al. (2013). Perendaman rebung dengan larutan SMB tidak menghilangkan aktivitas enzim PPO. Perendaman hanya menurunkan aktifitas enzim PPO jika dibandingkan dengan aktifitas enzim pada rebung tanpa perlakuan di waktu yang sama. Senyawa sulfit yang terkandung pada natrium metabisulfit tidak dapat secara mutlak menghentikan reaksi pencoklatan tetapi hanya memperlambat reaksi pencoklatan (Rahman, 2007). Hal ini disebabkan penambahan larutan metabisulfit sebagai senyawa anti-browning bekerja dengan cara membentuk ikatan disufida dengan enzim PPO sehingga menghambat pengikatan dengan oksigen (Candra et al., 2013). Akibatnya terbentuknya ikatan dengan disulfide menyebabkan aktifitas enzim menurun. Perendaman yang paling efektif menurunkan aktifitas enzim PPO dilakukan selama 45 menit menggunakan konsentrasi SMB 3000 ppm.

Sementara itu, Tabel 3. menunjukan rebung tanpa perlakuan mengalami penurunan total fenolik setelah disimpan. Hal ini kemungkinan karena selama penyimpanan, reaksi pencoklatan terus berlangsung.
Reaksi ini sendiri melibatkan senyawa fenolik sehingga semakin lama penyimpanan berarti senyawa fenolik yang ada semakin berkurang. Horwarth et al. (2013) mendapatkan hasil yang serupa dimana salah satu turunan senyawa fenolik yaitu total antosianin menurun setelah strawberi tanpa perlakuan disimpan hingga waktu tertentu.

Tabel 3 menunjukan perendaman rebung menggunakan SMB menyebabkan konsentrasi total fenolik yang terdeteksi setelah penyimpanan lebih tinggi dibanding total fenolik rebung tanpa perlakuan. Konsentrasi SMB dan waktu perendaman mampu menurunkan konsentrasi total fenolik yang terlibat dalam pencoklatan rebung. Hasil ini menunjukan bahwa oksidasi senyawa fenolik pada rebung dapat diperlambat dengan perendaman menggunakan SMB. Hal serupa juga dilaporkan Mishra et al. (2012) pada pencoklatan terong. Total senyawa fenolik pada buah kurma yang direndam dengan SMB juga dilaporkan meningkat (Amiour and Hambaba, 2016).

\section{Pengaruh $\mathrm{pH}$}

Pada tahap penelitian selanjutnya, perendaman dilakukan dengan variasi $\mathrm{pH}$ yaitu $3,4,6$, dan 8 pada konsentrasi SMB 3000 ppm selama 45 menit. Efek perendaman rebung pada berbagai $\mathrm{pH}$ ditunjukan pada Gambar 1, 2 dan 3. Gambar 1 menunjukan sampel dengan $\mathrm{pH}$ larutan selama perendaman tidak dikontrol mengalami penurunan derajat putih secara signifikan. Sedangkan pada $\mathrm{pH}$ larutan perendaman yang dikontrol, penurunan tercepat terjadi secata berturutan adalah derajat putih pada perlakuan $\mathrm{pH} 8,4$ dan 3 .

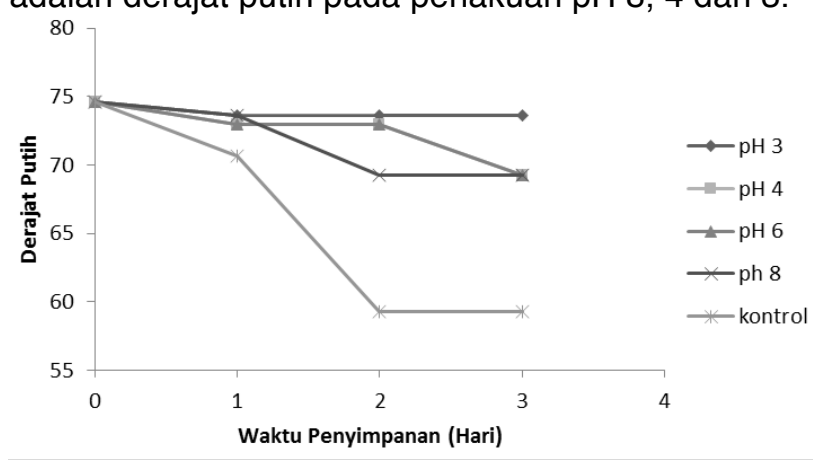

Gambar 1. Pengaruh pH terhadap Derajat Putih 
Derajat putih ditentukan oleh kombinasi beberapa faktor termasuk diantaranya aktifitas enzim PPO dan konsentrasi dan jenis senyawa fenolik. Nemenyi et al. (2015) melaporkan rebung dari taksa yang sama mempunyai total senyawa fenolik yang sangat bervariasi. Masing-masing turunan senyawa fenolik mempunyai pengaruh yang berbeda terhadap aktifitas PPO. Mengingat sampel pada penelitian ini diambil dari satu jenis rebung maka dapat diasumsikan kandungan jenis senyawa fenoliknya sama. Gambar 1 menunjukkan sampel dengan perlakuan basa memberi warna lebih coklat dibanding sampel dengan perlakuan asam. Gomes et al. (2014) mendapatkan pH dan jenis substrat saling mempengaruhi pencoklatan pada buah pir. Pada substrat jenis asam kafeik, katesin dan pirogallol, pencoklatan akan meningkat dari $\mathrm{pH}$ netral ke $\mathrm{pH}$ basa. Hal ini mengindikasikan rebung yang digunakan pada penelitian ini kemungkinan mengandung asam kafeik, katesin dan pirogallol. Park et al. (2010) melaporkan ditemukannya senyawa fenolik pada rebung seperti asam p-hydroxybenzok, katesin, asam kafeik, asam klorogenik, asam siringik, asam pcoumarik dan asam ferulik.

Lebih lanjut Tan et al. (2015) menerangkan pencegahan pencoklatan oleh sulfit disebabkan oleh reaksi antara sulfit dengan quinin, dan perendaman dengan larutan bisulfit efektif dalam mempertahankan timbulnya warna coklat pada buah dan sayur. Oksigen yang membantu reaksi pencoklatan diikat oleh radikal SO, sehingga reaksi pencoklatan dapat diturunkan kecepatannya. Selain itu, Park et al. (2010) melaporkan rebung mengandung asam askorbat yang merupakan senyawa antioksidan mencapai $230 \mathrm{mg} / 100 \mathrm{~g}$ basis kering. Keberadaan senyawa ini dapat menunda pencoklatan karena ikut berperan dalam mengikat oksigen.

Secara umum aktifitas enzim PPO semua sampel baik kontrol maupun sampel dengan perlakuan mengalami penurunan aktifitas enzim yang signifikan setelah disimpan selama satu hari. Setelah melewati satu hari, aktifitas enzim PPO menurun tetapi lebih perlahan (Gambar 2). Kontrol dan sampel yang direndam pada $\mathrm{pH} 8$ menunjukan kecepatan penurunan yang lebih besar dibanding sampel yang lain. Hasil ini sejalan dengan hasil yang diperoleh pada Gambar 1.

Amiour and Hambaba (2016) melaporkan aktifitas PPO buah kurma tertinggi terjadi pada $\mathrm{pH}$ 6,47,2 , dengan stabilitas tertinggi pada $\mathrm{pH} 7$. Stabilitas enzim ini masih tinggi ( $>80 \%$ ) pada $\mathrm{pH} 5,6-8$. Di luar rentang $\mathrm{pH}$ ini, aktifitas PPO menurun dengan drastis. Sementara itu, Mizobutsi et al. (2010) mendapatkan aktifitas tertinggi PPO kulit buah leci dicapai pada $\mathrm{pH}$ 6,5-7.5. Perbedaan kondisi $\mathrm{pH}$ yang memberikan aktifitas PPO tertinggi antara hasil penelitian ini dengan penelitian yang sudah ada kemungkinan disebabkan oleh perbedaan sumber enzim, metode ekstraski, kemurnian enzim, buffer dan substrat yang dipakai. Selain itu, Mizobutsi et al. (2010) menyarankan variasi aktifitas PPO pada berbagai $\mathrm{pH}$ ini menunjukan adanya perbedaan isoenzim yang terlibat dan mengakibatkan perbedaan sifat kinetik.

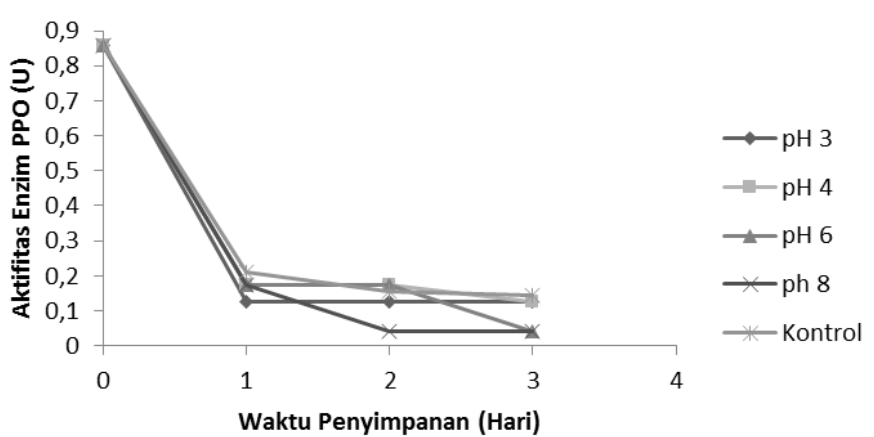

Gambar 2. Pengaruh pH terhadap Aktivitas Enzim PPO

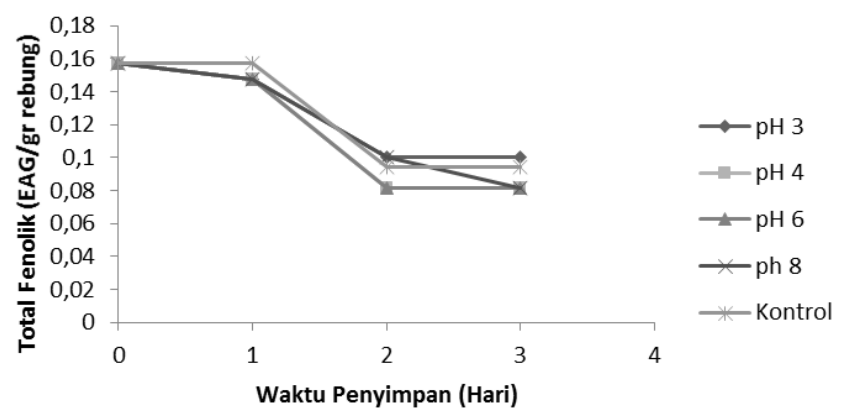

Gambar 3. Pengaruh pH terhadap Total Fenolik

Sementara itu, semua sampel menunjukan kecenderungan total fenolik yang sama (Gambar 3). Setelah penyimpanan 1 hari, konsentrasi total fenolik menunjukan penurunan yang signifikan di hari ke 2 diikuti penurunan yang lebih landai hingga hari ke 3 . Sampel yang direndam pada $\mathrm{pH} 4$ dan 6 mengalami penurunan yang lebih cepat dibanding sampel yang lain. Turunnya total fenolik ini disebabkan karena semakin lama waktu penyimpanan maka semakin banyak senyawa fenolik yang teroksidasi menjadi oquinon.

\section{Kesimpulan}

Konsentrasi SMB, waktu dan $\mathrm{pH}$ perendaman berpengaruh dalam mempertahankan derajat putih rebung. Konsentrasi SMB yang terbaik untuk mencegah pencoklatan rebung adalah $3000 \mathrm{ppm}$ dengan perendaman selama 45 menit. Perendaman pada $\mathrm{pH} 3$ dapat mempertahankan derajat putih rebung hingga bertahan disimpan selama 3 hari.

\section{Daftar Pustaka}

Amiour, S. D., and Hambaba, L. 2016. Effect of pH, temperature and some chemicals on polyphenoloxidase and peroxidase activities in harvested Deglet Nour and Ghars dates, Postharvest Biology and Technology, 111, 7782.

Chandra, A., Inggrid, H. M., dan Verawati. 2013. Pengaruh $\mathrm{pH}$ dan jenis pelarut pada perolehan dan karakterisasi pati dari biji alpukat, LPPM UNPAR, Bandung.

Chongtham, N., Bisht, M. S., and Haorongbam, S. 2011. Nutritional properties of bamboo shoots: potential and prospects for utilization as a health 
food, Comprehensive Reviews in Food Science and Food Safety, 10 (3), 153-168.

Choudhury, D., Sahu, J. K., and Sharma, G. D. 2012. Bamboo shoot: microbiology, biochemistry dan technology of fermentation-a review, Indian Journal of Traditional Knowledge, 11 (2), 242249.

Cortez-Vega, W. R., Becerra-Prado, A. M., Soares, J. M., and Fonscca, G. G. 2008. Effect of L-ascorbic acid and sodium metabisulfite in the inhibition of the enzymatic browning of minimally processed apple, International Journal of Agricultural Research, 3 (3), 196-201.

Coskun, A. L., Imaz, M. T., Aksu, O. T., Koç, B. E., Yemis, O., and Özkan, M. 2013. Effects of various sulphuring methods and storage temperatures on the physical and chemical quality of dried apricots, Food Chemistry, 141, 3670-3680.

Gardjito, M., Adnan, M., dan Trenggono. 2006. Etilen luka, aktivitas enzim peroksidase, polifenol oksidase, dan fenil alanin liase pada irisan mesokarp labu kuning, Agritech, 26 (1), 14-23.

Gomes, M. H., Vieira, T., Fundo, J. F., and Almeida, D. P. F. 2014. Polyphenoloxidase activity and browning in fresh-cut 'Rocha' pear as affected by $\mathrm{pH}$, phenolic substrates, and antibrowning additives, Postharvest Biology and Technology 91, 32-38.

Holzwarth, M., Wittig, J., Carle, R., and Kammerer, D. R. 2013. Influence of putative polyphenoloxidase (PPO) inhibitors on strawberry (Fragaria $x$ ananassa Duch.) PPO, anthocyanin and color stability of stored purées, LWT - Food Science and Technology, 52, 116-122.

Ioannou, I. and Ghoul, M. 2013 Prevention of enzymatic browning in fruit and vegetables, European Scientific Journal, 9 (30), 310-341.

Kuijpers, T. F. M., Verloop, A. J. W., Narvaez-Cuenca, C-E., van Berkel, W. J, H., Vincken, J-P., and Gruppen, H. 2012. Inhibition of enzymatic browning of chlorogenic acid by sulfurcontaining compounds, Journal of Agriculture Food Chemistry, 60, 3507-3514.

Luo, Z., Wu, X., Xie, Y., and Chen, C. 2012 Alleviation of chilling injury and browning of postharvest bamboo shoot by salicylic acid treatment, Food Chemistry, 131 (2), 456-461.

Mesquita, V. L. V. and Queiroz, C. 2013. Enzymatic browning, Biochemistry of Foods, $3^{\text {rd }} \mathrm{Ed}$, Editor Eskin, N. A. M. and Shahidi, F., Academic Press, Amsterdam, 387-418.

Mizobutsi, G. P., Finger, F. L., Ribeiro, R. A., Puschman, R., Neves, L. L. M., and Mota, W. F.
2010 Effect of $\mathrm{pH}$ and temperature on peroxidase and polyphenoloxidase activities of litchi pericarp, Science Agriculture (Piracicaba, Braz.), 67 (2), 213-217.

Mishra, B. B., Gautam, S., and Sharma, A. 2012. Browning of fresh-cut eggplant: impact of cutting and storage, Postharvest Biology and Technology, 67, 44-51.

Mohpraman, K. and Siriphanich, J. 2012 Safe use of sodium metabisulfite in young coconuts, Postharvest Biology and Technology, 65, 76-78.

Nastiti, M. A., Hendrawan, Y., dan Yulianingsih, R. 2014. Pengaruh konsentrasi natrium metabisulfit $\left(\mathrm{Na}_{2} \mathrm{~S}_{2} \mathrm{O}_{5}\right)$ dan suhu pengeringan terhadap karakteristik tepung ampas tahu, Jurnal Bioproses Komoditas Tropis, 2 (2), 100-106.

Nemenyi, A, Stefanovitsne-Banyai, E., Pek, Z., Hedegus, A., Gyutica, C, Barocsi, Z., and Helyes, L. 2015. Total antioxidant capacity and total phenolics contents of phyllostachys taxa shoots, Noe Boe horti Agrobo, 43 (1), 61-69.

Nemś, A.,Peksa, A., Kucharska, A. Z., Sokół-Łętowska, A., Kita, A., Drożdż, W., and Hamouz, K. 2015. Anthocyanin and antioxidant activity of snacks with coloured potato, Food Chemistry, 172, 175182.

Park, E-J. and Jhon, D-Y. 2010. The antioxidant, angiostensin converting enzyme inhibition activity, and phenolic compounds of bamboo shoot extracts, LWT-Food Science and Technology, 43, 655-659.

Prabasini, H., Ishartani, D., dan Rahadian, D. 2013. Kajian sifat kimia dan fisik tepung labu kuning (cucurbita moschata) dengan perlakuan blanching dan perendaman dalam natrium metabisulfit $\left(\mathrm{Na}_{2} \mathrm{~S}_{2} \mathrm{O}_{5}\right)$, Jurnal Teknosains Pangan, 2 (2), 93-102.

Queiroz, C., Lopes, M. L. M., Fialho, E., and Mesquita, V. L. V. 2008. Polyphenol oxidase: characteristics and mechanisms of browning control, Food Reviews International, 24, 361-375.

Rahman, F. 2007. Pengaruh konsentrasi natrium metabisulfit $\left(\mathrm{Na}_{2} \mathrm{~S}_{2} \mathrm{O}_{5}\right)$ dan suhu pengeringan terhadap mutu pati biji alpukat (Persea americana mill.), Skripsi, USU, Medan.

Tan, T. C., Cheng, L. H., Bhat, R., Rusul, G., and Easa, A. M. 2015. Effectiveness of ascorbic acid and sodium metabisulfite as anti-browning agent and antioxidant on green coconut water (Cocos nucifera) subjected to elevated thermal processing, International Food Research Journal, 22 (2), 631-637. 